\title{
Phenotypic and genetic effects of pregnancy on milk production traits in Holstein-Friesian cattle
}

\author{
Haibo Lu $\odot$ and Henk Bovenhuis* (ㄱ) \\ Animal Breeding and Genomics, Wageningen University and Research, PO Box 338, $6700 \mathrm{AH}$, Wageningen, the Netherlands
}

\begin{abstract}
Pregnancy is a prerequisite for the initiation of lactation and for maintaining the milk production cycle. Pregnancy affects milk production and therefore should be accounted for in the genetic evaluation. Furthermore, there might be genetic differences in pregnancy effects on milk composition. The objective of this study was to estimate phenotypic and genetic effects of pregnancy on milk production traits. For this purpose, test-day records and conception dates of 1,359 first-parity Holstein-Friesian cows were analyzed. Significant effects of pregnancy on all milk production traits were detected except somatic cell score (e.g., the cumulative effects of pregnancy on milk yield were $-247 \mathrm{~kg}$ ). The pregnancy effects on milk yield, lactose yield, protein yield, fat yield, and fat content were small during early gestation $(<150 \mathrm{~d})$ and substantially increased in late gestation. The effects of pregnancy on milk protein yield were relatively stronger than those on fat yield. The effects of pregnancy on milk production traits differed for DGAT1 genotypes. Milk yield, lactose yield, protein yield, and fat yield of DGAT1 AA cows were more affected by pregnancy than that of DGAT1 KK cows (e.g., the cumulative effects of pregnancy on milk yield were negligible for DGAT1 KK cows and were -443 $\mathrm{kg}$ for DGAT1 AA cows). These results suggest that $D G A T 1 \mathrm{KK}$ cows may be more suitable for shortening or omitting the dry period than DGAT1 AA cows.
\end{abstract}

Key words: pregnancy effect, DGAT1 by pregnancy stage interaction, nutrient allocation during pregnancy

\section{INTRODUCTION}

Pregnancy is a prerequisite for the initiation of lactation and for maintaining the milk production cycle. Pregnancy also affects milk production traits (Ragsdale et al., 1924; Erb et al., 1952; Coulon et al., 1995). It has been estimated that as a consequence of pregnancy,

Received March 19, 2020.

Accepted July 20, 2020.

*Corresponding author: henk.bovenhuis@wur.nl 305-d milk yield of a first-parity Holstein-Friesian cow is reduced by $207 \mathrm{~kg}$ as compared with a nonpregnant cow (Olori et al., 1997). Effects of pregnancy on milk yield and other milk production traits are relevant to the genetic evaluation of dairy cattle, and in several countries genetic evaluation accounts for pregnancy effects. Otherwise cows with better fertility, which are more likely to be pregnant, would be penalized in their breeding value for milk production traits (Olori et al., 1997; Bohmanova et al., 2009; Loker et al., 2009).

Pregnancy effects on milk production traits strongly depend upon the stage of pregnancy; effects of pregnancy on milk yield are small during early pregnancy $(<150$ d in gestation), after which effects start to increase nonlinearly (Olori et al., 1997; Bohmanova et al., 2009; Loker et al., 2009). Pregnancy effects in late gestation are relevant for assessing the impact of shortening or omitting the dry-off period; shortening the dry-off period will result in additional milk production that might compensate for decreased milk production in the next lactation (Kok et al., 2016). As pregnancy affects milk yield and composition, studies have been performed to investigate possibilities to predict pregnancy status based on milk infrared spectra (Toledo-Alvarado et al., 2018; Delhez et al., 2020). Pregnancy might also affect the genetic background of milk production traits. It has been found that effects of some genes related to milk production traits change during lactation and it has been suggested that changes during late lactation might be related to pregnancy (Lu and Bovenhuis, 2019; Lu et al., 2020). However, so far no studies have investigated if there are genetic differences in pregnancy effects on milk production traits. The objective of this study was to estimate the effects of pregnancy on milk production traits and to investigate if these effects differ between cows with different genotypes.

\section{MATERIALS AND METHODS}

\section{Data}

The cows for this study were part of the Dutch Milk Genomics Initiative and details about data collection 
and data structure can be found in Stoop et al. (2007). In brief, all cows were at least $87.5 \%$ Holstein-Friesian and were housed on 398 commercial herds with at least 3 cows per herd. For the current study, a subset of cows was selected from the original data set and selection was based on the possibilities to accurately predict date of conception. Cows were only selected if the calving date for the second parity and insemination records in first-parity were available. For those cows, date of conception was estimated based on the calving date for the second parity minus an average gestation length of $279 \mathrm{~d}$. Cows were only included in our analyses if the last registered insemination record in the first parity was within a 30-d interval of the estimated conception date $( \pm 15 \mathrm{~d})$. Of the available 1,800 first-parity cows, 1,359 cows met these criteria and were used for further analyses.

Test-day milk production records of 1,359 first-parity cows were available including milk yield, lactose yield, lactose content, protein yield, protein content, fat yield, fat content, and SCC. The total number of test-day records was 14,505 with slight differences between traits and each cow on average had 10.7 test-day records. All test-day records were obtained from routine milk recordings. Lactose, fat, and protein content were determined by infrared spectroscopy (MilkoScan FT 6000, Foss Electric, Hillerod, Denmark) at the milk control station laboratory (Qlip, Zutphen, the Netherlands). Lactose, fat, and protein yield were calculated by multiplying respective content by milk yield. Somatic cell count was determined using the Fossomatic 5000 (Foss Electric) and analyzed as SCS, i.e., $\log _{\mathrm{e}}(\mathrm{SCC})$.

\section{Pregnancy Effects on Milk Production Traits}

Pregnancy effects on milk production traits were estimated using the following model:

$$
\begin{gathered}
y_{j k l n o p q}=\mu+b_{1} \cdot a f_{j k l n o p q}+\text { season }_{j}+\text { scode }_{k}+\text { lact }_{l} \\
+P S_{n}+H T D_{o}+\text { animal }_{p}+p e_{q}+e_{j k l n o p q}
\end{gathered}
$$

where $y_{j k l n o p q}$ is the test-day milk production traits; $\mu$ is the overall mean; af $c_{j k l n o p q}$ is a covariate describing the effect of age at first calving and $b_{1}$ is the regression coefficient; season $n_{j}$ is the fixed effect of calving season (4 classes: August to October, November to January, February to April, and May to July); scode $e_{k}$ is the fixed effect accounting for possible differences in genetic level between proven bulls (638 daughters), test bulls (586 daughters), and other proven bulls (135 daughters); lact $_{l}$ is the fixed effect of lactation stage (26 stages of 15 $\mathrm{d}$ each); $P S_{n}$ is the fixed effect of pregnancy stage (stage 0 indicating the period before conception and 8 preg- nancy stages of $30 \mathrm{~d}$ each); $H T D_{o}$ is the random effect of herd-test-day, which is assumed to be distributed as $N\left(\mathbf{0}, \mathbf{I} \sigma_{H T D}^{2}\right)$, where $\mathbf{I}$ is an identity matrix and $\sigma_{H T D}^{2}$ is the herd-test-day variance; animal $l_{p}$ is the random additive genetic effect of the individual and assumed to be distributed as $N\left(\mathbf{0}, \mathbf{A} \sigma_{a}^{2}\right)$, where $\mathbf{A}$ is the additive genetic relationships matrix and $\sigma_{a}^{2}$ is the additive genetic variance; $p e_{q}$ is the permanent environmental effect and assumed to be distributed as $N\left(\mathbf{0}, \mathbf{I} \sigma_{p e}^{2}\right)$, where I is an identity matrix and $\sigma_{p e}^{2}$ is the permanent environmental variance; and $e_{j k l n o p q}$ is the random residual and assumed to be distributed as $N\left(\mathbf{0}, \mathbf{I} \sigma_{e}^{2}\right)$, where $\mathbf{I}$ is an identity matrix and $\sigma_{e}^{2}$ is the residual variance. The additive genetic relationship matrix (A) was constructed based on 14,062 animals (traced back 5 generations). The pedigree of the cows was provided by the Dutch herd book (CRV, Arnhem, the Netherlands). The model also included the effect of scode $e_{k}$. Proven bulls are not a random sample, but they are selected, and this might affect the estimated additive genetic variance. Possible differences in genetic level between groups of bulls are accounted for by the effect of scode $e_{k}$.

Lactation was truncated at $390 \mathrm{~d}$ instead of $305 \mathrm{~d}$, resulting in 26 lactation stage classes of $15 \mathrm{~d}$ each. Truncation at $390 \mathrm{~d}$ increased the number of test-day records in late lactation and the number of test-day records for late pregnancy stages. Test-day records before the conception date were assigned to pregnancy stage 0 and from the conception date onward 8 pregnancy stages of $30 \mathrm{~d}$ each were defined. After $240 \mathrm{~d}$ of pregnancy, most cows were dried off and the remaining 26 test-day records were excluded from the analysis.

The significance of $P S_{n}$ on milk production traits was tested using the Wald $F$-test statistic. Differences between estimated effects for pregnancy stage 0 and other pregnancy stages were tested using a $t$-test. If the $P$-value was $<0.001$, the effect of that pregnancy stage on a milk production trait was considered significantly different from the effect of pregnancy stage 0 .

\section{Genetic Differences in Pregnancy Effects}

In our previous studies we identified several QTL whose effects on milk production traits changed during lactation ( $\mathrm{Lu}$ and Bovenhuis, 2019; Lu et al., 2020). Some of the changes in genetic effects occur in early lactation and might be related to negative energy balance. Others occur in late lactation and we hypothesized that these changes might be related to pregnancy. We 
tested this hypothesis for the following SNP by trait combinations: rs29011303, rs43193272, rs41591350, and rs109651365 for protein content; rs523413537 for milk yield, lactose yield, protein content, and fat content; and rs41578697 for lactose content. The SNP genotypes were available based on a 50K SNP panel as described in Schopen et al. (2011). The SNP rs523413537 is 1 of the 2 SNP responsible for the diacylglycerol Oacyltransferase 1 (DGAT1) K232A polymorphism and therefore will be referred to as DGAT1 in the remaining part of this paper. The frequency of the DGAT1 K allele in the current population is 0.40 . To investigate the hypothesis that changes in SNP effects are related to pregnancy, we used the following model:

$$
\begin{gathered}
y_{j k l m n o p q}=\mu+b_{1} \cdot \text { afc }_{\text {jklmnop }}+\text { season }_{j}+\text { scode }_{k}+\text { lact }_{l} \\
+S N P_{m}+(S N P \times \text { lact })_{l m}+P S_{n}+(S N P \times P S)_{m n} \\
+H T D_{o}+\text { animal }_{p}+\text { pe }_{q}+e_{j k l m n o p q}
\end{gathered}
$$

where $S N P_{m}$ is the fixed effect of the SNP genotype (3 genotype classes); $(S N P \times l a c t)_{l m}$ is the genotype by lactation stage interaction, which allows SNP effects to change during lactation; and $(S N P \times P S)_{m n}$ is the genotype by pregnancy stage interaction, which allows SNP effects to change during pregnancy. Other model terms are as described for model [1].

The significance of $(S N P \times P S)_{m n}$ in model [2] was tested using the Wald $F$-test statistic. The test statistic of the interaction term is inflated ( $\mathrm{Lu}$ and Bovenhuis, $2019)$ and therefore the significance of the $(S N P \times P S)$ ${ }_{m n}$ model term was tested based on 1,000 permutations. In each permutation, $S N P$ genotypes were randomly reassigned to another animal. Subsequently, the permuted data were re-analyzed and the Wald $F$-test statistics of the $(S N P \times P S)_{m n}$ term were stored. These Wald $F$-test statistics were used to determine the $5 \%$ significance threshold level of the $(S N P \times P S)_{m n}$ interaction term. In case $(S N P \times P S)_{m n}$ was significant, a $t$-test was used to test if genotypes significantly differed within a pregnancy stage. If the $P$-value was smaller than 0.001 , the SNP effect within that pregnancy stage was considered significant. All the analysis were performed in Asreml (Gilmour et al., 2006).

\section{RESULTS AND DISCUSSION}

\section{Pregnancy Effects on Milk Production Traits}

The number of records, mean, and standard deviation for the test-day milk production traits, days open, and age at first calving for 1,359 first-parity HolsteinFriesian cows are in Table 1. On average, cows were pregnant at $130 \mathrm{~d}$ after calving, but there were substan-
Table 1. Descriptive statistics of test-day milk production traits, days open, and age of first calving for 1,359 first-parity Holstein-Friesian cows

\begin{tabular}{lccc}
\hline Trait & Number & Mean & SD \\
\hline Milk yield $(\mathrm{kg} / \mathrm{d})$ & 14,505 & 24.63 & 5.30 \\
Lactose yield (kg/d) & 14,341 & 1.15 & 0.25 \\
Lactose content (\%) & 14,341 & 4.65 & 0.14 \\
Protein yield (kg/d) & 14,469 & 0.86 & 0.17 \\
Protein content (\%) & 14,469 & 3.51 & 0.31 \\
Fat yield (kg/d) & 14,460 & 1.06 & 0.22 \\
Fat content (\%) & 14,460 & 4.37 & 0.63 \\
SCS & 13,555 & 4.14 & 1.02 \\
Days open (d) & 1,359 & 130 & 77 \\
Age at first calving (yr) & 1,359 & 2.13 & 0.16 \\
\hline
\end{tabular}

tial differences; the days open range from $55 \mathrm{~d}$ ( 5 th percentile) to $284 \mathrm{~d}$ (95th percentile) in lactation. These large differences in conception date allow disentangling the effects of pregnancy and lactation stage. Average age at first calving was $2.13 \mathrm{yr}$ and ranged from 1.80 to 2.98 yr.

Pregnancy had significant effects on all milk production traits except SCS (model [1]). Figure 1 shows the estimated effects of the different pregnancy stages on milk production traits. In Figure 1 traits were expressed in phenotypic standard deviations to make effect sizes comparable across traits. Cumulative pregnancy effects were calculated as the cumulative differences between pregnant and nonpregnant cows (pregnancy stage 0 ). Cumulative effects of pregnancy over pregnancy stages 1 through 8, that is, $\sum_{n=0}^{n=7} 0.5 \cdot 30 \cdot\left(P S_{n}+P S_{n+1}\right)$, on milk yield were $-247 \mathrm{~kg}$, on lactose yield $-11.6 \mathrm{~kg}$, on protein yield $-10.4 \mathrm{~kg}$, and on fat yield $-8.2 \mathrm{~kg}$. When expressed in phenotypic standard deviations, pregnancy effects on protein yield were more pronounced than those on fat yield (Figure 1). The effects of pregnancy on lactose content and protein content were small. Pregnancy effects on milk yield, lactose yield, protein yield, fat yield, and fat content were relatively small in early pregnancy and became more important in late pregnancy [e.g., pregnancy effects on milk yield from stage 5 (d 150) onward accounted for $88 \%$ of the total cumulative effects of pregnancy on milk yield].

For first-parity Holstein-Friesian cows, Olori et al. (1997) estimated pregnancy effects on 305-d milk production of $-207 \mathrm{~kg}$ of milk, $-10.7 \mathrm{~kg}$ of lactose, -8.7 $\mathrm{kg}$ of protein, and $-8.1 \mathrm{~kg}$ of fat. For Canadian Ayrshire, Loker et al. (2009) estimated pregnancy effects of $-222 \mathrm{~kg}$ of milk, $-10.0 \mathrm{~kg}$ of protein, and $-7.3 \mathrm{~kg}$ of fat. The latter estimates were based on the first-, second-, and third-parity test-day records with DIM $\geq 5$ and $\leq 365$ (Loker et al., 2009). These pregnancy effects on milk production traits differ slightly from the estimates in the current study. Like the current study, 

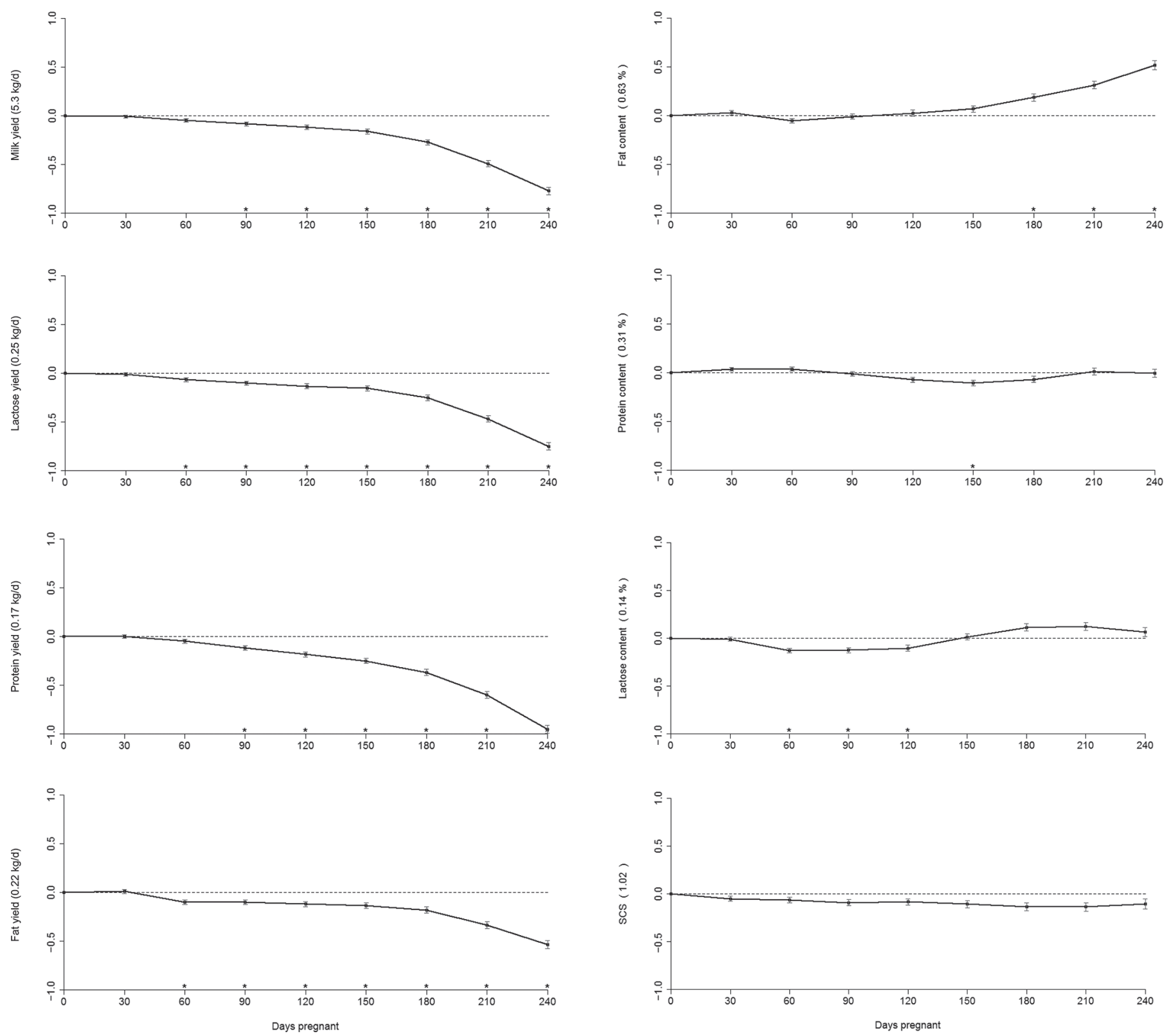

Figure 1. Estimated effects $( \pm \mathrm{SE})$ of pregnancy on milk production traits for different pregnancy stages. The y-axis is scaled by the phenotypic standard deviation (in parentheses) of the corresponding traits. The dashed line indicates the effect of pregnancy stage 0 (nonpregnant). A significant $(P<0.001)$ difference between effects of a pregnancy stage and pregnancy stage 0 based on a $t$-test is indicated by *.

other studies also reported more pronounced effects of pregnancy on protein yield than on fat yield (Olori et al., 1997; Bohmanova et al., 2009; Loker et al., 2009). Milk lactose is the major component for milk osmosis and does not show much variation (Fox et al., 2015; Costa et al., 2019). This explains why milk lactose content is not strongly affected by pregnancy. The effects of pregnancy on protein content are also small, which is due to relatively similar pregnancy effects on protein yield and milk yield. Consequently, the effect of pregnancy on protein content (i.e., the ratio of protein yield over milk yield) is small. Similar to the current study, other studies also reported that pregnancy effects on milk yield, lactose yield, protein yield, fat yield, and fat content mainly occur during late gestation (e.g., Olori et al., 1997; Bohmanova et al., 2009; Penasa et al., 2016).

Pregnancy effects on milk production traits are likely due to nutrient partitioning during gestation (Bauman and Currie, 1980; Bell, 1995). The availability and allocation of nutrients during gestation involves feed intake, nutrient absorption, milk production, maintenance, 
Table 2. The $P$-values for SNP by pregnancy stage interaction of a selected set of $\mathrm{SNP}^{1}$ whose effects change during late lactation

\begin{tabular}{lcclc}
\hline SNP & BTA & Position $^{2}(\mathrm{bp})$ & Trait & $\begin{array}{c}P \text {-value } \\
(\mathrm{SNP} \times \mathrm{PS})\end{array}$ \\
\hline rs29011303 & 3 & $93,216,176$ & Protein content & 0.54 \\
rs43193272 & 9 & $85,934,554$ & Protein content & 0.89 \\
rs41591350 & 10 & $48,721,829$ & Protein content & 0.66 \\
rs523413537 & 14 & 445,087 & Milk yield & $<0.001$ \\
rs523413537 & 14 & 445,087 & Lactose yield & $<0.001$ \\
rs523413537 & 14 & 445,087 & Protein content & 0.004 \\
rs523413537 & 14 & 445,087 & Fat content & 0.73 \\
rs41578697 & 19 & $57,745,840$ & Lactose content & 0.78 \\
rs109651365 & 27 & $37,915,598$ & Protein content & \\
\hline
\end{tabular}

${ }^{1} \mathrm{SNP}$ were from studies by Lu and Bovenhuis (2019) and Lu et al. (2020). SNP rs523413537 is 1 of the 2 SNP responsible for the DGAT1 K232A polymorphism.

${ }^{2} \mathrm{SNP}$ position based on Btau 4.0.

${ }^{3}$ The $P$-values for genotype by pregnancy stage interaction $(\mathrm{SNP} \times \mathrm{PS})$ were based on 1,000 permutations.

body reserve, and fetus development. In addition, for primiparous cows part of their body growth takes place during the first lactation and therefore growth is an additional nutrient demanding process. Pregnancy effects on milk production traits might therefore be due to several factors, one of them being that nutrients partitioned to fetus development are no longer available for milk production. Stronger effects of pregnancy on protein yield than fat yield might be related to the requirements of the fetus; protein requirement of the fetus is nearly twice that of the fat requirement (Prior and Laster, 1979). Increased pregnancy effects toward late gestation on milk yield, lactose yield, protein yield, and fat yield is also in line with the nutrient requirements of the fetus; growth of the fetus increases exponentially from d 160 in gestation onward. In the last 2 mo of pregnancy (i.e., the period during which most cows are dried off), the fetus acquires around $60 \%$ of its birth weight (Prior and Laster, 1979; Bauman and Currie, 1980; Bell et al., 1995; Krog et al., 2018). For management purposes, it is assumed that the energy required for the development of the fetus is nonsignificant during early gestation and extra energy for gestation is only considered from $190 \mathrm{~d}$ in gestation onward (NRC, 2001).

\section{Genetic Differences in Pregnancy Effects}

In previous studies we identified chromosomal regions whose effects change during late lactation and hypothesized that these changes might be related to pregnancy (Lu and Bovenhuis, 2019; Lu et al., 2020). The lead SNP of the chromosomal regions previously identified for specific SNP by trait combinations are shown in Table 2, and it was tested if changes in these SNP effects can be attributed to pregnancy. The SNP rs523413537 on BTA14 (DGAT1) showed significant
SNP by pregnancy stage interactions $(S N P \times P S)$ for milk yield, lactose yield, and protein content. For the other 6 SNP by trait combinations, we did not find evidence that changes in SNP effects during lactation can be attributed to pregnancy. In our previous study, changing DGAT1 effects during late lactation on milk yield, lactose yield, protein content, and fat content were detected based on stringent genome-wide significance thresholds ( $\mathrm{Lu}$ and Bovenhuis, 2019; Lu et al., 2020), which reduces detection power. However, it is well documented that the DGAT1 polymorphism has major effects on several milk production traits (e.g., Grisart et al., 2002; Bovenhuis et al., 2016). Therefore, the DGAT1 by pregnancy stage interaction for other milk production traits (protein yield, fat yield, lactose content, and SCS) were also tested using model [2], and significant interactions were detected for protein yield $(P=0.008)$ and fat yield $(P=0.009)$.

The estimated effects of DGAT1 during pregnancy on milk yield, lactose yield, protein yield, fat yield, and protein content are shown in Figure 2. The estimated effects for SNP by pregnancy stage interaction were from model [2] without the main effects of SNP and pregnancy stage. Figure 2 shows that milk yield, lactose yield, protein yield, and fat yield of DGAT1 AA cows are more affected by pregnancy than those of DGAT1 KK cows. For DGAT1 KK cows, pregnancy reduced milk yield, lactose yield, protein yield, and fat yield from d 180 in pregnancy onward, for AK cows reduction in milk yield, lactose yield, protein yield, and fat yield started around d 120 in pregnancy, and for AA cows pregnancy affected milk yield, lactose yield, protein yield, and fat yield shortly after conception. Figure 2 also shows that differences in protein content for cows with different DGAT1 genotypes are relatively constant throughout gestation but differences between genotypes tend to decrease toward late gestation. Estimates 

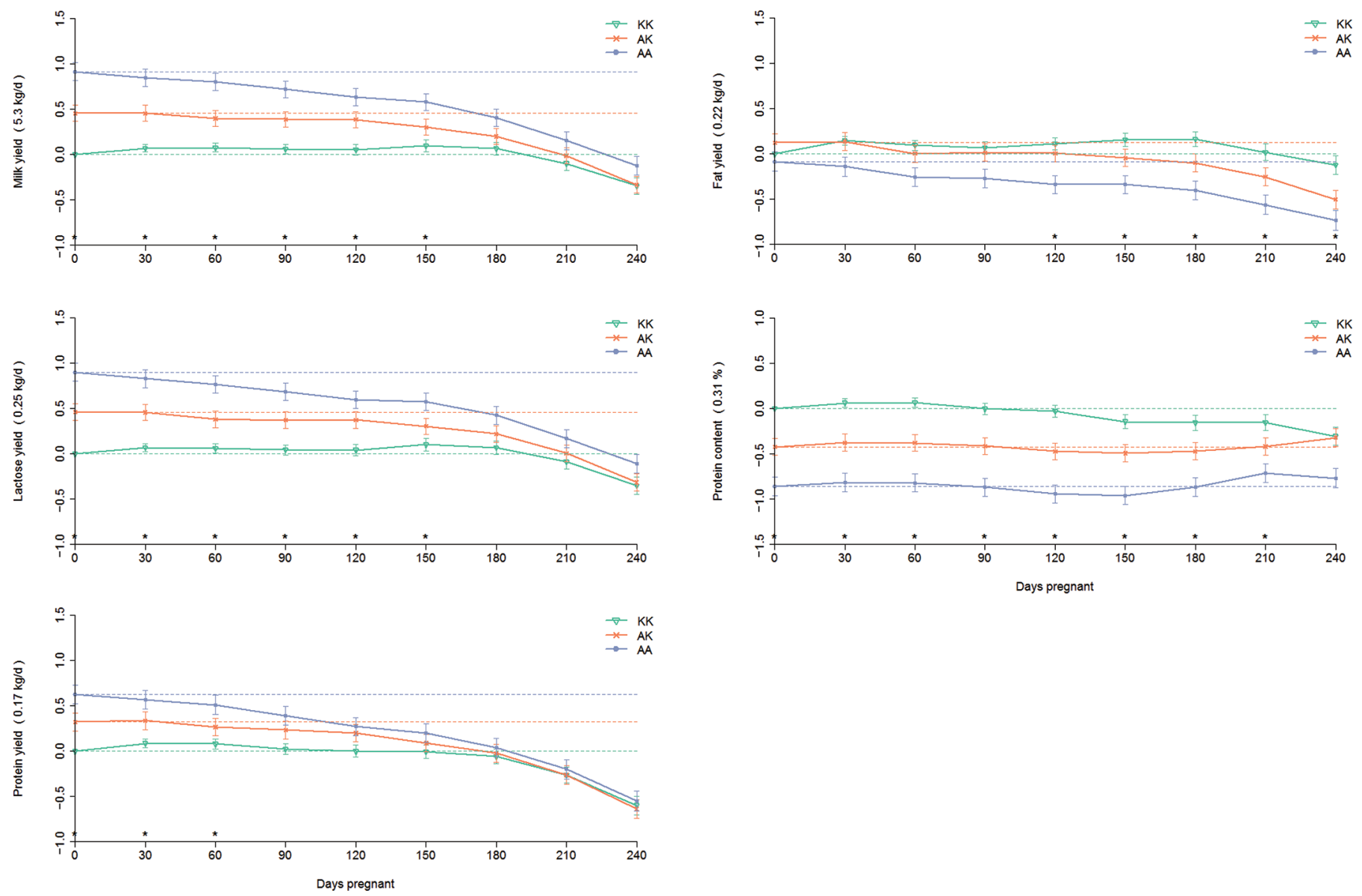

Figure 2. Effects $( \pm \mathrm{SE})$ of $D G A T 1$ genotypes on milk yield, lactose yield, protein yield, fat yield, and protein content during pregnancy. The effects were estimates for SNP by pregnancy stage interaction from a model without main effects of SNP and pregnancy stage. The y-axis is scaled by the phenotypic standard deviation (in parentheses) of the corresponding trait. The dashed line indicates the effects of pregnancy stage 0 (nonpregnant), separately for each $D G A T 1$ genotype. ${ }^{*}$ indicates a significant $(P<0.001)$ difference between any 2 SNP genotype classes in that specific pregnancy stage based on a $t$-test.

for cumulative pregnancy effects on milk yield, lactose yield, protein yield, and fat yield over pregnancy stages 1 through 8 for cows with different DGAT1 genotypes are shown in Table 3. Effects differed substantially for DGAT1 genotypes (e.g., pregnancy effects were -443 $\mathrm{kg}$ of milk for AA cows, $-233 \mathrm{~kg}$ for AK cows, and 26 $\mathrm{kg}$ for KK cows). For KK cows the estimated effects of pregnancy from d 1 through d 180 were small and positive, and cumulative effects over pregnancy from d 180 to 240 were $-36.5 \mathrm{~kg}$ of milk.

Differences in pregnancy effects between cows with $D G A T 1$ genotypes might be due to differences in fertil- ity; cows with a higher number of days open might show smaller effects of pregnancy on milk production. Therefore, we also compared days open for cows with different DGAT1 genotypes; for AA cows this was 127 d, for AK cows it was $136 \mathrm{~d}$, and for KK cows it was $123 \mathrm{~d}$. These differences were not significant and cannot explain the observed differences between DGAT1 genotypes in pregnancy effects on milk production traits. Pregnancy effects on milk production might be due to changes in the allocation of nutrients during gestation that involves feed intake, milk synthesis, maintenance, body reserve, fetus development, and growth for pri-

Table 3. Cumulative effects $(\mathrm{kg})$ of pregnancy on first-parity milk yield, lactose yield, protein yield, and fat yield for cows with different DGAT1 genotypes

\begin{tabular}{lcccc}
\hline DGAT1 & Milk yield & Lactose yield & Protein yield & Fat yield \\
\hline AA & -443 & -20.6 & -16.3 & -13.5 \\
AK & -233 & -11.2 & -9.7 & -9.4 \\
KK & 26 & 1.0 & -2.2 & 4.6 \\
\hline
\end{tabular}


miparous cows (Bauman and Currie, 1980; Bell, 1995). Milk production of KK cows was less affected by pregnancy than that of AA cows, which might indicate that KK cows partition fewer nutrients from milk synthesis to fetal growth. If so, the birth weight of calves from KK cows should be lower than calves from AA cows and consequently $\mathrm{KK}$ cows would have less calving problems than AA cows. However, there is currently no evidence that KK cows produce calves with lower birth weight (Cole et al., 2014) and have better calving ease than AA cows (Berry et al., 2010). There also might be alternative explanations for the observed effects of DGAT1 genotypes (e.g., differences in feed intake, body reserve, and age of first calving). However, Banos et al. (2008) did not detect significant effects of DGAT1 genotypes on feed intake and body reserve. Furthermore, in the current population age at first calving was not significantly affected by the DGAT1 polymorphism (results not shown). Therefore, the physiological background of observed differences in pregnancy effects of DGAT1 genotypes on milk production traits requires further investigation.

Conventionally, dairy cows are dried off in late gestation and in negative energy balance after calving due to the peak production and constrained feed intake (e.g., Collard et al., 2000; de Vries and Veerkamp, 2000). Alternative management strategies such as shortening or omitting the dry-off period have been proposed to reduce peak production after caving (e.g., Chen et al., 2015; Kok et al., 2017; van Hoeij et al., 2017). This management strategy results in additional milk yield during late gestation and decreased milk yield in the next lactation. Kok et al. (2016) suggested that the suitability of this management strategy should be assessed with consideration of milk yield during the last $60 \mathrm{~d}$ in gestation (i.e., the conventional dry-off period). Our study showed that milk yield during late gestation was affected by pregnancy and effects of pregnancy differ between cows with different DGAT1 genotypes. This suggests that the suitability of cows for shortening or omitting the dry-off period might depend upon their DGAT1 genotype. Further research is needed to study how cows with different DGAT1 genotypes respond to shortening or omitting the dry-off period.

It has been suggested that after $150 \mathrm{~d}$ in gestation pregnancy status can be predicted based on milk infrared spectra (Lainé et al., 2017; Toledo-Alvarado et al., 2018; Delhez et al., 2020). Such information might be used as a complementary tool to detect fetal abortion (Delhez et al., 2020). The current study shows that there are significant differences in pregnancy effects on milk production traits between cows with different DGAT1 genotypes. Milk production traits of DGAT1 KK cows are hardly affected by pregnancy. Therefore, accuracy of predicting pregnancy based on milk infrared spectra might be poor. Effects of pregnancy for DGAT1 AA cows are stronger and start earlier in pregnancy, which might result in higher prediction accuracies. Wang and Bovenhuis (2020) demonstrated that combining milk infrared spectra with genotypic information can improve prediction of milk fat composition. Therefore, accounting for genetic differences in pregnancy effects might improve prediction of pregnancy by milk infrared spectra.

\section{CONCLUSIONS}

Significant effects of pregnancy on milk production traits were detected. Pregnancy effects on milk yield, lactose yield, protein yield, fat yield, and fat content were mainly observed during late pregnancy (>d 150). Pregnancy effects on protein yield were higher than those on fat yield. Interestingly, pregnancy effects on milk yield, lactose yield, protein yield, fat yield, and protein content differed considerably between cows with different DGAT1 genotypes.

\section{ACKNOWLEDGMENTS}

This study used data from Dutch Milk Genomics Initiative project, funded by Wageningen University and Research (Wageningen, the Netherlands), the Dutch Dairy Association NZO (Zoetermeer, the Netherlands), Cooperative Cattle Improvement Organization CRV (Arnhem, the Netherlands), and the Dutch Technology Foundation STW (Utrecht, the Netherlands). SinoDutch Dairy Development Centre (Beijing, China) is acknowledged for financially supporting Haibo Lu. Yachun Wang (China Agricultural University, Beijing, China) is acknowledged for discussion. The authors have not stated any conflicts of interest.

\section{REFERENCES}

Banos, G., J. A. Woolliams, B. W. Woodward, A. B. Forbes, and M. P. Coffey. 2008. Impact of single nucleotide polymorphisms in leptin, leptin receptor, growth hormone receptor, and diacylglycerol acyltransferase (DGAT1) gene loci on milk production, feed, and body energy traits of UK dairy cows. J. Dairy Sci. 91:3190-3200. https: //doi.org/10.3168/jds.2007-0930.

Bauman, D. E., and W. B. Currie. 1980. Partitioning of nutrients during pregnancy and lactation: A review of mechanisms involving homeostasis and homeorhesis. J. Dairy Sci. 63:1514-1529. https:// doi.org/10.3168/jds.S0022-0302(80)83111-0.

Bell, A. W. 1995. Regulation of organic nutrient metabolism during transition from late pregnancy to early lactation. J. Anim. Sci. 73:2804-2819. https://doi.org/10.2527/1995.7392804x.

Bell, A. W., R. Slepetis, and U. A. Ehrhardt. 1995. Growth and accretion of energy and protein in the gravid uterus during late pregnancy in Holstein cows. J. Dairy Sci. 78:1954-1961. https://doi .org/10.3168/jds.S0022-0302(95)76821-7. 
Berry, D. P., D. Howard, P. O'Boyle, S. Waters, J. F. Kearney, and M. McCabe. 2010. Associations between the K232A polymorphism in the diacylglycerol-O-transferase 1 (DGAT1) gene and performance in Irish Holstein-Friesian dairy cattle. Ir. J. Agric. Food Res. 49:1-9.

Bohmanova, J., J. Jamrozik, and F. Miglior. 2009. Effect of pregnancy on production traits of Canadian Holstein cows. J. Dairy Sci. 92:2947-2959. https://doi.org/10.3168/jds.2008-1782.

Bovenhuis, H., M. H. P. W. Visker, N. A. Poulsen, J. Sehested, H. J. F. van Valenberg, J. A. M. van Arendonk, L. B. Larsen, and A. J. Buitenhuis. 2016. Effects of the diacylglycerol O-acyltransferase 1 (DGAT1) K232A polymorphism on fatty acid, protein, and mineral composition of dairy cattle milk. J. Dairy Sci. 99:3113-3123. https://doi.org/10.3168/jds.2015-10462.

Chen, J., J. J. Gross, H. A. van Dorland, G. J. Remmelink, R. M. Bruckmaier, B. Kemp, and A. T. M. Van Knegsel. 2015. Effects of dry period length and dietary energy source on metabolic status and hepatic gene expression of dairy cows in early lactation. J. Dairy Sci. 98:1033-1045. https://doi.org/10.3168/jds.2014-8612.

Cole, J. B., B. Waurich, M. Wensch-Dorendorf, D. M. Bickhart, and H. H. Swalve. 2014. A genome-wide association study of calf birth weight in Holstein cattle using single nucleotide polymorphisms and phenotypes predicted from auxiliary traits. J. Dairy Sci. 97:3156-3172. https://doi.org/10.3168/jds.2013-7409.

Collard, B. L., P. J. Boettcher, J. C. M. Dekkers, D. Petitclerc, and L. R. Schaeffer. 2000. Relationships between energy balance and health traits of dairy cattle in early lactation. J. Dairy Sci. 83:2683-2690. https://doi.org/10.3168/jds.S0022-0302(00)75162 -9 .

Costa, A., N. Lopez-Villalobos, N. W. Sneddon, L. Shalloo, M. Franzoi, M. De Marchi, and M. Penasa. 2019. Invited review: Milk lactose-Current status and future challenges in dairy cattle. J. Dairy Sci. 102:5883-5898. https://doi.org/10.3168/jds.2018-15955.

Coulon, J. B., L. Pérochon, and F. Lescourret. 1995. Modelling the effect of the stage of pregnancy on dairy cows' milk yield. Anim. Sci. 60:401-408. https://doi.org/10.1017/S1357729800013278.

de Vries, M. J., and R. F. Veerkamp. 2000. Energy balance of dairy cattle in relation to milk production variables and fertility. J. Dairy Sci. 83:62-69. https://doi.org/10.3168/jds.S0022-0302(00)74856-9.

Delhez, P., P. N. Ho, N. Gengler, H. Soyeurt, and J. E. Pryce. 2020. Diagnosing the pregnancy status of dairy cows: How useful is milk mid-infrared spectroscopy? J. Dairy Sci. 103:3264-3274. https:// doi.org/10.3168/jds.2019-17473.

Erb, R. E., M. M. Goodwin, R. A. Morrison, and A. O. Shaw. 1952. Lactation studies. I. Effect of gestation. J. Dairy Sci. 35:224-233. https://doi.org/10.3168/jds.S0022-0302(52)93695-3.

Fox, P. F., T. Uniacke-Lowe, P. L. H. McSweeney, and J. A. O'Mahony. 2015. Dairy Chemistry and Biochemistry, Second Edition. Springer International Publishing, Basel, Switzerland.

Gilmour, A. R., B. J. Gogel, B. R. Cullis, S. J. Welham, and R. Thompson. 2006. ASReml User Guide Release 1.0. VSN International Ltd., Hemel Hempstead, UK.

Grisart, B., W. Coppieters, F. Farnir, L. Karim, C. Ford, P. Berzi, N. Cambisano, M. Mni, S. Reid, P. Simon, R. Spelman, M. Georges, and R. Snell. 2002. Positional candidate cloning of a QTL in dairy cattle: identification of a missense mutation in the bovine DGAT1 gene with major effect on milk yield and composition. Genome Res. 12:222-231. https://doi.org/10.1101/gr.224202.

Kok, A., A. T. M. van Knegsel, C. E. van Middelaar, B. Engel, H. Hogeveen, B. Kemp, and I. J. M. de Boer. 2017. Effect of dry period length on milk yield over multiple lactations. J. Dairy Sci. 100:739-749. https://doi.org/10.3168/jds.2016-10963.

Kok, A., C. E. van Middelaar, B. Engel, A. T. M. van Knegsel, H. Hogeveen, B. Kemp, and I. J. M. de Boer. 2016. Effective lactation yield: A measure to compare milk yield between cows with different dry period lengths. J. Dairy Sci. 99:2956-2966. https:// doi.org/10.3168/jds.2015-10559.
Krog, C. H., J. S. Agerholm, and S. S. Nielsen. 2018. Fetal age assessment for Holstein cattle. PLoS One 13:e0207682. https://doi.org/ 10.1371/journal.pone.0207682.

Lainé, A., C. Bastin, C. Grelet, H. Hammami, F. G. Colinet, L. M. Dale, A. Gillon, J. Vandenplas, F. Dehareng, and N. Gengler. 2017. Assessing the effect of pregnancy stage on milk composition of dairy cows using mid-infrared spectra. J. Dairy Sci. 100:28632876. https://doi.org/10.3168/jds.2016-11736.

Loker, S., F. Miglior, J. Bohmanova, J. Jamrozik, and L. R. Schaeffer. 2009. Phenotypic analysis of pregnancy effect on milk, fat, and protein yields of Canadian Ayrshire, Jersey, Brown Swiss, and Guernsey breeds. J. Dairy Sci. 92:1300-1312. https://doi.org/10 $.3168 /$ jds.2008-1425.

Lu, H., and H. Bovenhuis. 2019. Genome-wide association studies for genetic effects that change during lactation in dairy cattle. J. Dairy Sci. 102:7263-7276. https://doi.org/10.3168/jds.2018-15994.

Lu, H., Y. Wang, and H. Bovenhuis. 2020. Genome-wide association study for genotype by lactation stage interaction of milk production traits in dairy cattle. J. Dairy Sci. 103:5234-5245. https://doi .org/10.3168/jds.2019-17257.

NRC. 2001. Nutrient Requirements of Dairy Cattle. 7th rev. ed. Natl. Acad. Press, Washington, DC.

Olori, V. E., S. Brotherstone, W. G. Hill, and B. J. McGuirk. 1997. Effect of gestation stage on milk yield and composition in Holstein Friesian dairy cattle. Livest. Prod. Sci. 52:167-176. https://doi .org/10.1016/S0301-6226(97)00126-7.

Penasa, M., M. De Marchi, and M. Cassandro. 2016. Short communication: Effects of pregnancy on milk yield, composition traits, and coagulation properties of Holstein cows. J. Dairy Sci. 99:48644869. https://doi.org/10.3168/jds.2015-10168.

Prior, R. L., and D. B. Laster. 1979. Development of the bovine fetus. J. Anim. Sci. 48:1546-1553. https://doi.org/10.2527/jas1979 $.4861546 \mathrm{x}$.

Ragsdale, A. C., C. W. Turner, and S. Brody. 1924. The effect of gestation upon lactation in the dairy cow. J. Dairy Sci. 7:24-30. https: /doi.org/10.3168/jds.S0022-0302(24)93991-9.

Schopen, G. C. B., M. H. P. W. Visker, P. D. Koks, E. Mullaart, J. A. M. van Arendonk, and H. Bovenhuis. 2011. Whole-genome association study for milk protein composition in dairy cattle. J. Dairy Sci. 94:3148-3158. https://doi.org/10.3168/jds.2010-4030.

Stoop, W. M., H. Bovenhuis, and J. A. van Arendonk. 2007. Genetic parameters for milk urea nitrogen in relation to milk production traits. J. Dairy Sci. 90:1981-1986. https://doi.org/10.3168/jds .2006-434.

Toledo-Alvarado, H., A. I. Vazquez, G. de los Campos, R. J. Tempelman, G. Bittante, and A. Cecchinato. 2018. Diagnosing pregnancy status using infrared spectra and milk composition in dairy cows. J. Dairy Sci. 101:2496-2505. https://doi.org/10.3168/jds.2017 $-13647$.

van Hoeij, R. J., J. Dijkstra, R. M. Bruckmaier, J. J. Gross, T. J. G. M. Lam, G. J. Remmelink, B. Kemp, and A. T. M. van Knegsel. 2017. The effect of dry period length and postpartum level of concentrate on milk production, energy balance, and plasma metabolites of dairy cows across the dry period and in early lactation. J. Dairy Sci. 100:5863-5879. https://doi.org/10.3168/jds.2016-11703.

Wang, Q., and H. Bovenhuis. 2020. Combined use of milk infrared spectra and genotypes can improve prediction of milk fat composition. J. Dairy Sci. 103:2514-2522. https://doi.org/10.3168/jds .2019-16784.

\section{ORCIDS}

Haibo Lu ৫ https://orcid.org/0000-0003-1155-8942 Henk Bovenhuis 우 https://orcid.org/0000-0002-9074-5334 